\title{
Fine Needle Aspiration Cytology of Palpable Breast Lump: A Study of 1778 Cases
}

\section{Rahman $\mathrm{MZ}^{1 *}$ and Islam $\mathrm{S}^{2}$}

${ }^{1} \mathrm{Head}$ of the Department, Department of Pathology, Chittagong Medical College, Chittagong, Bangladesh

${ }^{2}$ Lecturer in Pathology, Department of Pathology, Chittagong Medical College, Chittagong, Bangladesh

\begin{abstract}
Background: Breast carcinoma is the most common malignant tumour and the leading cause of death from cancer in women. A large number of patients in Bangladesh have been suffering from breast cancer. Now-a-days, FNAC is being performed as a pre-operative test to evaluate breast lump. FNAC is cost effective and can prevent unnecessary surgery. As FNAC became more reliable in diagnosing malignancy and thereby the use of frozen-section histology had been reduced by about $80 \%$. This study intended to look the frequencies of different lesions in FNAC of palpable breast lump.
\end{abstract}

Methods: FNAC was done in a total of 1778 female patients presented with palpable breast lump along with suspected enlarged axillary lymph node, if any. We assessed the age of the patient, lesion size, site, type of lesion and axillary lymph node metastasis in case of malignancies.

Results: Age ranges from 14-86 years with a mean age of 33.6 years. Most of the patients were in 21-30 years age group (38.13\%). Among the lesions $508(28.57 \%)$ fibroadenoma, $252(14.17 \%)$ carcinoma, $210(11.81 \%)$ fibrocystic changes, $141(7.93 \%)$ abscess, $116(6.52 \%)$ granulomatous lesion, $113(6.3 \%)$ chronic mastitis were identified. $218(42.91 \%)$ of fibroadenoma and $82(32.54 \%)$ of carcinoma were in the age group 21-30 years and 31-40 years respectively. Mean lesion size was $4.3 \pm 2 \mathrm{~cm}$. Site distribution in different cases is almost equal. 116 of carcinoma patient were presented with palpable lymph node and showed metastasis in $26(10.32 \%)$ cases.

Conclusion: FNAC serves as a rapid, economical, and reliable tool for the diagnosis of palpable breast lesions because the cytopathological examination of these lesions before operation or treatment, serves as an important diagnostic modality. Fibroadenoma was the commonest lesion in this study. However, malignancy was detected as the second common lesion.

Keywords: Fine Needle Aspiration Cytology (FNAC); Breast lump

Abbreviations: FNAC: Fine Needle Aspiration Cytology; AFB: Acid Fast Bacillus; UK: United Kingdom; FCD: Fibrocystic Disease; ADH: Atypical Duct Hyperplasia; DCIS: Ductal Carcinoma In Situ

\section{Introduction}

Breast carcinoma is the most common malignant neoplasm and the leading cause of death from cancer in women, with more than 1 million cases occurring worldwide annually [1]. However, in some regions of the world (North America, Western Europe and Australia) breast cancer mortality is finally beginning to fall, presumably because of the combined action of earlier diagnosis and improved therapy [2]. Countries with traditionally low incidence however are now experiencing the increase in the new registration also. A large number of patients in Bangladesh have been suffering from breast cancer. Each year the number of patients is increasing. Because of existing social circumstances female patients are hesitant to be examined by the clinicians for breast lump, the patients are reporting in advanced stage of malignancy.

Now-a-days, FNAC is being performed as a pre-operative test to evaluate the breast lump. A study of Khatun et al. [3] in the year 2000 evaluated the accuracy of FNAC on 310 patients presented with palpable breast lumps showed a very high sensitivity, specificity and accuracy. FNAC can prevent unnecessary surgery also. FNAC could provide a diagnosis with only $10-30 \%$ of the cost of surgical biopsy [4]. $95 \%$ accuracy in preoperative diagnosis of mammary cancer by clinicocytological combination was reported in a study [5]. As FNAC became more reliable in diagnosing malignancy and thereby the use of frozensection histology had been reduced by about $80 \%$ [6]. The present study is intended to look the frequency distribution of different lesions in FNAC of palpable breast lumps.

\section{Material and Methods}

The aim of the study was to see the distribution of different types of breast lesions among females of Chittagong in Bangladesh with the approval of ethical committee of Chittagong Medical College, Chittagong, Bangladesh. Female patients presenting with palpable breast lump were included in this study. In a period of three years, FNAC of consecutive 1778 patients were done after taking informed written consent. At least four slides were made from the aspirates. Palpable axillary lymph node was also selected for FNAC, if any. All the slides were stained with Pap stain and examined under light microscope. Data was recorded regarding the age of the patient, site of involvement, size of the lesion, cytological diagnosis and presence of metastasis in case of malignancies.

\section{Results}

The patients were from 14-86 years of age with a mean of 33.61 years. 21-30 years age group comprises most of the patient (678 $=38.13 \%)$ followed by $31-40$ years age group $(428=24.07 \%)$. Among

\footnotetext{
*Corresponding author: Mohammad Zillur Rahman, Associate Professor of Pathology, Head of the Department, Department of Pathology, Chittagong Medical College, Chittagong, Bangladesh, Tel: +880-1819-315116; E-mail: drzillur@gmail.com

Received December 29, 2012; Accepted January 27, 2013; Published February 05, 2013

Citation: Rahman MZ, Islam S (2013) Fine Needle Aspiration Cytology of Palpable Breast Lump: A Study of 1778 Cases. Surgery S12: 001. doi:10.4172/2161-1076. S12-001

Copyright: (c) 2013 Rahman MZ, et al. This is an open-access article distributed under the terms of the Creative Commons Attribution License, which permits unrestricted use, distribution, and reproduction in any medium, provided the original author and source are credited.
} 
Citation: Rahman MZ, Islam S (2013) Fine Needle Aspiration Cytology of Palpable Breast Lump: A Study of 1778 Cases. Surgery S12: 001. doi:10.4172/2161-1076.S12-001

Page 2 of 5

the type of the lesions, fibroadenoma showed the highest $(508=28.57 \%)$ incidence followed by carcinoma $(252=14.17 \%)$ and fibrocystic disease $(210=11.81 \%)$ cases. Inflammatory lesions were abscess $141(7.93 \%)$, chronic mastitis $113(6.36 \%)$, granulomatous mastitis 116 (6.52\%) and fat necrosis $06(0.34 \%) .308(17.3 \%)$ cases designated as 'others' included fatty tissue, unsatisfactory smears.

Highest number of fibroadenoma (218) was in the age group of 21-30 years and the $<20$ years group was second (196). Maximum of carcinoma cases were in the age group of 31-40 and 41-50 years of age group ( 82 and 59 respectively). Among the inflammatory lesions, highest number was seen in the age group of the 21-30 years group (Table 1).

We found 116 (6.52\%) cases of granulomatous mastitis. Among them $58(50 \%)$ were non-caseating, $58(50 \%)$ were caseating consistent with tuberculosis. Among the caseating granuloma cases, 31 (26.72\%) were associated with suppuration. Ziehl-Neelsen stain of the suspected tuberculosis cases was done and found 12 cases positive for Acid Fast Bacilli (AFB) (Table 2).

The mean age of the suspicious for malignant cases were $44.89 \pm$ 8.51 years, malignant cases were $44.38 \pm 13.12$ years and of the other cases were $30.24 \pm 10.99$ years (Table 3 ). Regarding side involvement, almost in all cases either left or right side involvement was nearly equal (Table 4). Mean lesion size of all 1778 breast lumps were $4.3 \pm 2.7 \mathrm{~cm}$ and mean lesion size of 252 carcinoma cases were: $2.3 \pm 1.2 \mathrm{~cm}$. Among malignant lesions $60.71 \%$ were presented with a size less than $2 \mathrm{~cm}$ and $36.51 \%$ presented with $2-5 \mathrm{~cm}$ (Table 5).
Among 252 Duct cell carcinoma patient only 116 showed palpable axillary lymph nodes and $26(10.32 \%)$ cases of these showed presence of metastasis and rest 90 (35.71\%) were reactive lymph nodes (Table 6).

\section{Discussion}

The study population ranged from 14-86 years with a mean age of 33.6 years. Ahmed et al. [7] from Sudan reported 15-85 years of age range with a mean of 37 years. Bukhari et al. [8] showed a range of 16-70 years in Pakistan, Kumar [9] reported 6-72 years and Tiwari [10] 17-56 years in Nepal with a mean age of 34 and 32 years respectively and 18 92 years with a mean age of 59.3 years were reported by Dennison et al. [11] in United Kingdom (UK). The higher age range of this study from Nepal and Pakistan may be explained by the increased life expectancy rates from those countries. Again the lower age range from the study of UK is also may be due to lower life expectancy rate of Bangladesh compared to UK.

In this study, the lesion presented in the right breast was $49.05 \%$ and the left breast was $47.55 \%$ and $3.4 \%$ cases involved both. Kumar [9] observed a deviation from our results with a little predominance of right breast (51.4\%). This might an incidental findings and it required very large group population based study to find out any significant difference. Regarding malignant cases we observed $49.60 \%$ cases involved the right side, $48.81 \%$ involved the left and $1.59 \%$ involved both. Rupom et al. [12] found $58.18 \%$ of malignant lesion in the right breast. Again it may be due to smaller number of cases (55) for which their result did not correspond with ours.

\begin{tabular}{|c|c|c|c|c|c|c|c|c|c|}
\hline Lesion Category & Diagnosis & Upto 20 years & $21-30$ years & $31-40$ years & $41-50$ years & $51-60$ years & $>60$ years & Total & $\%$ \\
\hline \multirow{4}{*}{ Inflammation } & Abscess & 06 & 69 & 41 & 16 & 05 & 04 & 141 & 7.93 \\
\hline & Chronic Mastitis & 27 & 48 & 21 & 13 & 03 & 01 & 113 & 6.36 \\
\hline & Granuloma Mastitis & 05 & 63 & 34 & 11 & 03 & 00 & 116 & 6.52 \\
\hline & Fat necrosis & 01 & 01 & 04 & 00 & 00 & 00 & 06 & 0.34 \\
\hline \multirow{3}{*}{ Cystic lesion } & Galactocele & 05 & 30 & 07 & 01 & 00 & 00 & 43 & 2.42 \\
\hline & Benign cystic lesion & 01 & 11 & 04 & 06 & 01 & 00 & 23 & 1.29 \\
\hline & Fibrocystic disease & 06 & 78 & 63 & 48 & 11 & 04 & 210 & 11.81 \\
\hline \multirow{3}{*}{ Benign neoplasm } & Lactating adenoma & 03 & 02 & 00 & 00 & 00 & 00 & 05 & 0.28 \\
\hline & Fibroadenoma & 196 & 218 & 68 & 22 & 04 & 00 & 508 & 28.57 \\
\hline & Benign Phyllodes & 00 & 00 & 02 & 03 & 00 & 00 & 05 & 0.28 \\
\hline \multirow{2}{*}{ Atypia } & $\mathrm{ADH}$ & 00 & 05 & 06 & 07 & 02 & 00 & 20 & 1.12 \\
\hline & Suspicious malignancy & 00 & 00 & 09 & 14 & 03 & 02 & 28 & 1.60 \\
\hline Malignant neoplasm & Carcinoma & 03 & 36 & 82 & 59 & 46 & 26 & 252 & 14.17 \\
\hline \multirow{2}{*}{ Others } & Fatty tissue & 07 & 16 & 12 & 14 & 05 & 06 & 60 & 3.36 \\
\hline & Inadequate smears & 29 & 101 & 75 & 18 & 20 & 05 & 248 & 13.94 \\
\hline \multicolumn{2}{|l|}{ Total } & 289 & 678 & 428 & 232 & 103 & 48 & 1778 & 100 \\
\hline
\end{tabular}

Table 1: Frequency distribution of different categories of lesions according to age groups.

\section{Granulomatous inflammation}

Non caseating granulomatous inflammation Caseating granuloma consistent with tuberculosis Caseating granuloma associated with suppuration Total

\begin{tabular}{|c|c|c|}
\multicolumn{2}{|c|}{ Frequency } & AFB positive \\
\hline 58 & 50.00 & Not done \\
\hline 27 & 23.28 & 7 \\
\hline 31 & 26.72 & 5 \\
\hline 116 & 100.00 & 12 \\
\hline
\end{tabular}

Table 2: Frequency distribution of types of granulomatous mastitis.

\begin{tabular}{|l|c|c|c|c|}
\hline Diagnoses & N & Mean & SD & Median \\
\hline Suspicious Malignancy & 28 & 44.89 & 8.51 & 44.00 \\
\hline Carcinoma & 252 & 44.38 & 13.12 & 42.00 \\
\hline Rests & 1498 & 30.24 & 10.99 & 29.00 \\
\hline Total & 1778 & 33.61 & 12.41 & $14-86$ \\
\hline
\end{tabular}

Table 3: Statistics of age (years) among different diagnoses. 


\begin{tabular}{|l|c|c|c|c|c|c|c|}
\hline \multirow{2}{*}{ Category } & \multicolumn{2}{|c|}{ Right } & \multicolumn{2}{c|}{ Left } & \multicolumn{2}{c|}{ Both } & Total \\
\cline { 2 - 8 } & $\mathbf{n}$ & $\mathbf{\%}$ & $\mathbf{n}$ & $\mathbf{\%}$ & $\mathbf{n}$ & $\%$ & \\
\hline Inflammation & 193 & 51.33 & 176 & 46.81 & 7 & 1.86 & 376 \\
\hline Cystic lesion & 142 & 51.45 & 122 & 44.20 & 12 & 4.25 & 276 \\
\hline Benign neoplasm & 238 & 45.95 & 253 & 48.84 & 27 & 5.21 & 518 \\
\hline Atypia & 23 & 47.92 & 25 & 52.08 & - & - & 48 \\
\hline Malignant neoplasm & 125 & 49.60 & 123 & 48.81 & 04 & 1.59 & 252 \\
\hline Total & 721 & 49.05 & 699 & 47.55 & 50 & 3.40 & 1470 \\
\hline
\end{tabular}

Table 4: Side involvement by different lesion.

\begin{tabular}{|l|c|c|c|c|c|}
\hline \multirow{2}{*}{ Carcinoma } & \multicolumn{3}{|c|}{ Size of the malignant breast lesion } & \multirow{2}{*}{ Total } & $\begin{array}{c}\text { Palpable } \\
\text { Axillary LN }\end{array}$ \\
\cline { 2 - 6 } & $<\mathbf{2} \mathbf{~ c m}$ & $\mathbf{2 - 5} \mathbf{~ c m}$ & $\mathbf{> 5} \mathbf{~ c m}$ & & 116 \\
\hline $\begin{array}{l}\text { Duct cell } \\
\text { carcinoma }\end{array}$ & $\begin{array}{c}153 \\
(60.71 \%)\end{array}$ & $91(36.11 \%)$ & $07(2.78 \%)$ & 251 & 00 \\
\hline Lobular carcinoma & 00 & $01(0.40 \%)$ & 00 & 01 & 00 \\
\hline
\end{tabular}

Table 5: Size of malignant breast lesion.

\begin{tabular}{|l|c|c|}
\hline Lymph Node & No. of cases & $\%$ \\
\hline Metastatic & 26 & 10.32 \\
\hline Reactive & 90 & 35.71 \\
\hline Not Palpable & 136 & 53.97 \\
\hline Total & 252 & 100.00 \\
\hline
\end{tabular}

Table 6: Axillary lymph node status in the carcinoma patients.

Regarding inflammatory lesions of the breast, this study found total $21.15 \%$ cases. This result are supported by the findings from Pakistan by Bukhari et al. [8] 20\%, from Nepal by Kumar [9] 22.6\%, though findings of Nemaqani and Yaqoob [13] showed little higher (26.5\%) from Kingdom of Saudi Arabia. The major difference of this study was that we found $6.52 \%$ of granulomatous mastitis cases which was reported very low in their studies; $2.3 \%$ by Bukhari et al. [8] and none by Kumar [9].

Among the granulomatous mastitis we found 27 (23.28\%) cases of caseating granuloma, $31(26.72 \%)$ cases of caseating granuloma with suppuration and 58 (50\%) cases of granulomatous mastitis of unknown etiology. Tse et al. [14] reported $31 \%$ with suppuration among their 26 case of granulomatous mastitis and Lacambra et al. [15] reported from HongKong 29 (46.77\%) cases of tuberculosis mastitis among total 62 cases which also included associated supportive cases. The difference from the study of Bukhari et al. [8] is may be due to their smaller sample size. Though Lacambra et al. [15] reported 28 cases but they were found in eight years timeframe. Our study showed as many cases found within three years and this reflected the burden of tuberculosis in this region due to overpopulation, poor hygiene and malnutrition. We also did Ziehl-Neelsen stain of the suspected tuberculosis cases and found 12 cases positive for AFB. Though it is ideal to go for a PCR analysis for the detection of mycobacterium DNA, but this is not much available and affordable here.

We also found 43 (2.42\%) cases of galactocele, revealed milk during aspiration and microscopically histiocyte in the background of milk. Majority of the cases were in the age group of 21-30 yrs which is the most active reproductive years.

There were 23 (1.29\%) cases in which serous fluid mixed with blood came out on aspiration and subsequently under microscope histiocytes and chronic inflammatory cells. In all cystic masses, re-aspiration of any residual mass is recommended [16] and even in the absence of a residual mass. Re-aspiration of the wall of the cyst yielded fairly cellular smears with more likelihood of viable epithelial cells. The cyst wall could also presumably be a good target for the detection of associated epithelial proliferative lesions with or without atypia.
Regarding fibrocystic disease of breast, we found 210 (11.81\%) cases in this study. There incidence were highest in the 21-30 yrs age group $(78=37.14 \%)$ and second highest in $30-40$ years age group $(63=30 \%)$. In the study of Kumar [9] we can see fibrocystic disease (FCD) comprises $41.2 \%$ with an average age of 31 years and most of the cases were within the age group of 30-40 years. FCD also consist the highest number of FNAC cases $(49 \%)$ in the other study from Nepal by Pradhan and Dhakal [17]. Bukhari et al. [8] found 90 (21.17\%) FCD in their study was 425 cases in Pakistan. The number of FCD in our study is much lower than the above mentioned studies. The possible reason may be that, since it is not a population based study, we may not get the exact scenario. Besides, FCD presents with ill defined mass with no pain or less complaints. Female may feel reluctant to seek consultation for this type of lesion. And also the number of cases is much higher than the other three studies which also may contribute to the discrepancies.

Fibroadenoma was the major (28.57\%) cause of the breast lump in this study. 218 (42.9\%) and $196(38.58 \%)$ were in the age group of 21-30 and $<20$ years age group respectively. This finding was similar (28\%) to the findings of Ahmed et al. [7] from Sudan among their 200 cases. And near similar to the findings of Kumar [9] and Mayun et al. [18] as their result were $22 \%$ and $23.7 \%$. Besides Bukhari et al. [8] showed $16 \%$ and Pradhan and Dhakal [17] showed only $8 \%$ of fibroadenoma cases. The higher rate than the last two studies was perhaps caused by increased awareness among young women about the breast lump in this country. Our study showed much lower rate of fibroadenoma when compared to the study of Rahman et al. [19] (38.3\%), which may be explained by their smaller sample size. On the other hand, it was not a population based study, rather sampled consecutively from the patients attending the laboratory for FNAC with complaints of breast lump. Mayun et al. [18] found average age of fibroadenoma was 16 years but this study found most of the cases in the age group of 21-30 years. This demands further investigation to find out whether there is any cause of this age difference in relation to inhabitation or ethnicity.

A total number of $20(1.12 \%)$ cases of atypical duct hyperplasia $(\mathrm{ADH})$ were found. This study also reports $28(1.60 \%)$ cases of suspicious for malignant cells. Pradhan and Dhakal [17] reported 2.3\%, Yip et al. [20] 3.81\% and Ahmed et al. [7] 2.5\%. They needed core biopsy for confirmation of malignancy. Bukhari and Akhtar [21] and Bukhari et al. [8] found $11.42 \%$ and $8.4 \%$ suspicious cell for malignancy respectively. 139 (9\%) cases were atypical/suspicious for malignancy reported by Rosa et al. [22] and 51 (3.3\%) atypical by Yeoh and Chan [23]. Cytologic atypia comprises nuclear pleomorphism, loss of cohesiveness, irregular nuclear contours, irregular chromatin pattern, hyperchromasia, and high nuclear/cytoplasmic ratio. Architectural atypia corresponds to cribriform clusters, overlapping, and crowding $[24,25]$. For practical purposes, $\mathrm{ADH}$ and low grade DCIS (ductal carcinoma in situ) are better categorized as proliferative breast disease with atypia/borderline lesions since all of these lesions will require excisional biopsy [26,27].

Considering malignant cases in female breast, we found 252 (14.17\%) carcinoma cases, among which 251 cases were duct cell carcinoma and only one was lobular carcinoma. Previous study in this country by Rupom et al. [12] showed $13.74 \%$ (72/524) of malignant cases in FNAC. Pradhan and Dhakal [17] also reported 15.5\% malignant cases among their 2246 cases which are close to our study. Though Yip et al. [20] and Bukhari and Akhter [21] found near results but their numbers of cases were relatively smaller, 676 and 175 respectively. Ahmed et al. [7] in Sudan, Mayun et al. [18] in Nigeria and Bukhari et al. [8] in Pakistan reported 30.5\%, 40\% and 31\% malignant cases which reflects less awareness of women to attend health facilities with smaller 
Citation: Rahman MZ, Islam S (2013) Fine Needle Aspiration Cytology of Palpable Breast Lump: A Study of 1778 Cases. Surgery S12: 001. doi:10.4172/2161-1076.S12-001

Page 4 of 5

breast lumps but an ugly looking or very painful lesion. In this country, earlier study in 2002 by Khatun et al. [3] showed only 14/310 (4.32\%) of malignant cases indicating higher cancer burden or higher percentage of reporting. 31-40 age group showed highest number of malignant cases 82 (32.54\%) and 41-50 years group showed 59 (23.41\%) and we may conclude the majority (55.95\%) of the patient found in the middle age from 31-50 years. Majority of the patients (65.8\%) in the age group of 31- 50 years were also observed by Sandhu et al. [28] in India and Rupom et al. [12] found highest frequency in the $4^{\text {th }}$ decade of life.

However, reports from the western world show that female breast carcinoma is predominantly seen in the fifth and sixth decade [29-31]. Farooq and Coleman [32] compare age incidence between the South Asian and Non- South Asian breast carcinoma patient in England and Wales and found mean age at diagnosis of the South Asian women were 51.8 years compared with 62.8 years for non-south Asians and $16 \%$ (compared with 5\%) aged under 40 years at diagnosis.

So we also conclude with Sandhu et al. [28] that mean age of our female breast cancer patients was found to be lower compared to the western world with an average difference of one decade. Early age of menopause in Indian females in comparison to their western counterparts has been observed in the past [33]. The earlier published reports also show that the risk of breast carcinoma increases with increasing age of menopause, possibly because the women are exposed to hormones for a longer duration [34-36].

During aspiration, we found 116 of 252 breast carcinoma with palpable lymph node. 26 (10.32\%) of them showed features of metastasis duct cell carcinoma. Sapino et al. [37] found 49 (16.44\%) malignant cases with metastasis and Sinha et al. [38] reported $45.76 \%$ with metastatic axillary lymph node. Findings of Sapino et al. [37] is consistent with our findings and the discrepancies from that of Sinha et al. [38] is due to their very small sample size compared to other two studies. There was no scope of the study to find any other metastatic foci.

The number of cases those were included in 'others' comprised of 248 (13.94\%) inadequate aspirates and 60 (3.36\%) fatty tissue. Inadequacy of the aspirated material for cytological diagnosis has been reported $20 \%$ and $25.3 \%$ by Hitchcock et al. [39] and Park and Ham [40] and it reduces the sensitivity of the cytology. Our study showed $14 \%$ inadequacy. Bukhari et al. [8] reported 20\% inadequacy and reduced the number by repeating up to twice. Insufficient cases require re-evaluation of clinical and radiological findings as well as adequate follow-up, mostly in cases of palpable breast abnormalities [22].

\section{Conclusion}

Fibroadenoma is the commonest lesion in this study and is found mostly in the age group of 21-30 years. Malignancy was detected as the second common lesion and majority was found in 31-40 years age group. Breast carcinoma patients of this region are at the lower age of one decade than that of western women. Caseating granulomatous mastitis due to tuberculosis is increasing in Bangladesh.

\section{Authors' contribution}

1. Mohammad Zillur Rahman: Aspiration from breast lumps, examination of the smears, FNAC reporting, paper composing and editing.

2. Saiful Islam: Counseling, taking consent, data entry, record keeping, data compilation, internet searching for references, paper composing \& editing

\section{Acknowledgement}

Dr. Manjurul Hakim: For data analysis.

\section{References}

1. Parkin DM, Bray F, Ferlay J, Pisani $P$ (2001) Estimating the world cancer burden: Globocan 2000. Int J Cancer 94: 153-156.

2. Jatoi I, Miller AB (2003) Why is breast cancer mortality declining? Lancet Onco 4: 251-254.

3. Khatun H, Tareak-Al-Nasir, Enam S, Hussain M, Begum M (2002) Correlation of fine needle aspiration cytology and its histopathology in diagnosis of breast lumps. Bangladesh Med Res Counc Bull 28: 77-81.

4. Kaminsky DB (1981) Aspiration biopsy of the community hospital. Masson Pub USA.

5. Russ JE, Winchester DP, Scanlon EF, Christ MA (1978) Cytologic findings of aspiration of tumors of the breast. Surg Gynecol Obstet 146: 407-411.

6. Gardecki TI, Hogbin BM, Melcher DH, Smith RS (1980) Aspiration cytology in the preoperative management of breast cancer. Lancet 2: 790-792.

7. Ahmed HG, Ali AS, Almobarak AO (2009) Utility of fine-needle aspiration as a diagnostic technique in breast lumps. Diagn Cytopathol 37: 881-884.

8. Bukhari MH, Arshad M, Jamal S, Niazi S, Bashir S, et al. (2011) Use of fineneedle aspiration in the evaluation of breast lumps. Patholog Res Int 2011 689521

9. Kumar R (2010) A clinicopathologic study of breast lumps in Bhairahwa, Nepal. Asian Pac J Cancer Prev 11: 855-858.

10. Tiwari M (2007) Role of fine needle aspiration cytology in diagnosis of breast lumps. Kathmandu Univ Med J (KUMJ) 5: 215-217.

11. Dennison G, Anand R, Makar SH, Pain JA (2003) A prospective study of the use of fine-needle aspiration cytology and core biopsy in the diagnosis of breast cancer. Breast J 9: 491-493.

12. Rupom TU, Choudhury T, Banu SG (2011) Study of Fine Needle Aspiration Cytology of Breast Lump: Correlation of Cytologically Malignant Cases with Their Histological Findings. BSMMU J 4: 60-64.

13. Nemenqani D, Yaqoob N (2009) Fine needle aspiration cytology of inflammatory breast lesions. J Pak Med Assoc 59: 167-170.

14. Tse GM, Poon CS, Ramachandram K, Ma TK, Pang LM, et al. (2004) Granulomatous mastitis: a clinicopathological review of 26 cases. Pathology 36: 254-257.

15. Lacambra M, Thai TA, Lam CC, Yu AM, Pham HT, et al. (2011) Granulomatous mastitis: the histological differentials. J Clin Pathol 64: 405-411.

16. Jayaram G, Gupta M (1994) Fine needle aspiration cytology of benign breast lumps: a review of experience with 651 cases. Malays J Pathol 16: 29-38.

17. Pradhan M, Dhakal HP (2008) Study of breast lump of 2246 cases by fine needle aspiration. JNMA J Nepal Med Assoc 47: 205-209.

18. Mayun AA, Pindiga UH, Babayo UD (2008) Pattern of histopathologica diagnosis of breast lesions in Gombe, Nigeria. Niger J Med 17: 159-162.

19. Rahman MZ, Sikder AM, Nabi SR (2011) Diagnosis of breast lump by fine needle aspiration cytology and mammography. Mymensingh Med J 20: 658 664

20. Yip $\mathrm{CH}$, Jayaram G, Alhady SF (2000) The experience with fine needle aspiration cytology in the management of palpable breast lumps in the University Hospital Kuala Lumpur. Med J Malaysia 55: 363-367.

21. Bukhari MH, Akhtar ZM (2009) Comparison of accuracy of diagnostic modalities for evaluation of breast cancer with review of literature. Diagn Cytopathol 37 416-424.

22. Rosa M, Mohammadi A, Masood S (2010) The value of fine needle aspiration biopsy in the diagnosis and prognostic assessment of palpable breast lesions. Diagn Cytopathol.

23. Yeoh GP, Chan KW (1998) Fine needle aspiration of breast masses: an analysis of 1533 cases in private practice. Hong Kong Med J 4: 283-288.

24. Masood S (1995) Cytopathology of the breast. ASCP Press, Chicago.

25. Ducatman BS, Cibas CS (2003) Cytology: diagnostic principles and clinical correlates. (2ndedn), Saunders, Philadelphia.

26. Ellis OI, Schnitt SJ, Sastre-Garau X (2003) Invasive breast carcinoma. In: Tavassoli FA, Devillee P (eds) Pathology and Genetics of Tumours of the Breast and Female Genital Organs. IARC Press, Lyon. 
Citation: Rahman MZ, Islam S (2013) Fine Needle Aspiration Cytology of Palpable Breast Lump: A Study of 1778 Cases. Surgery S12: 001. doi:10.4172/2161-1076.S12-001

27. Zhao C, Raza A, Martin SE, Pan J, Greaves TS, et al. (2009) Breast fine-needle aspiration samples reported as "proliferative breast lesion": clinical utility of the subcategory "proliferative breast lesion with atypia". Cancer 117: 137-147

28. Sandhu DS, Sandhu S, Karwasra RK, Marwah S (2010) Profile of breast cance patients at a tertiary care hospital in north India. Indian J Cancer 47: 16-22.

29. Department of Health, Great Britain (1995) Hospital Episode Statistics Volume 2. Department of Health. London.

30. Anderson WF, Chatterjee N, Ershler WB, Brawley OW (2002) Estrogen receptor breast cancer phenotypes in the Surveillance, Epidemiology, and End Results database. Breast Cancer Res Treat 76: 27-36.

31. El-Tamer MB, Wait RB (1999) Age at presentation of African-American and Caucasian breast cancer patients. J Am Coll Surg 188: 237-240.

32. Farooq S, Coleman MP (2005) Breast cancer survival in South Asian women in England and Wales. J Epidemiol Community Health 59: 402-406.

33. Bharadwaj JA, Kendurkar SM, Vaidya PR (1983) Age and symptomatology of menopause in Indian women. J Postgrad Med 29: 218-222.
34. McPherson K, Steel CM, Dixon JM (2000) ABC of breast diseases. Breast cancer-epidemiology, risk factors, and genetics. BMJ 321: 624-628.

35. Alberg AJ, Lam AP, Helzlsouer KJ (1999) Epidemiology, prevention, and early detection of breast cancer. Curr Opin Oncol 11: 435-441.

36. Trichopoulos D, MacMahon B, Cole P (1972) Menopause and breast cance risk. J Natl Cancer Inst 48: 605-613.

37. Sapino A, Cassoni P, Zanon E, Fraire F, Croce S, et al. (2003) Ultrasonographically-guided fine-needle aspiration of axillary lymph nodes: role in breast cancer management. Br J Cancer 88: 702-706.

38. Sinha S, Sinha N, Bandyopadhyay R, Mondal SK (2009) Robinson's cytological grading on aspirates of breast carcinoma: Correlation with Bloom Richardson's histological grading. J Cytol 26: 140-143.

39. Hitchcock A, Hunt CM, Locker A, Koslowski J, Strudwick S, et al. (1991) A one year audit of fine needle aspiration cytology for the pre-operative diagnosis of breast disease. Cytopathology 2: 167-176.

40. Park IA, Ham EK (1997) Fine needle aspiration cytology of palpable breast lesions. Histologic subtype in false negative cases. Acta Cytol 41: 1131-1138. 